\title{
The Effects of Glucocorticoids on Fetal and Placental Development
}

\author{
Emin Turkay Korgun, Aslı Ozmen, Gozde Unek and Inanc Mendilcioglu
}

Additional information is available at the end of the chapter

http://dx.doi.org/10.5772/50103

\section{Introduction}

Glucocorticoids (GCs), steroid hormones produced predominantly by the adrenal gland, are key mediators of stress responses. Whilst the acute and chronic effects of pharmacological glucocorticoid excess are well-recognized (including induction of hyperglycemia, insulin resistance, hyperlipidemia, hypertension and dysphoria, with suppression of immune, inflammatory and cognitive processes), their role in the biology of the response to stress is more nuanced, with balanced homeostatic effects to facilitate short-term survival and recovery from challenge [1, 2]. In addition, glucocorticoids play an essential role in normal fetal development and are important for the development and maturation of various fetal tissues including the liver, lungs, gut, skeletal muscle and adipose tissue in preparation for extrauterine life. Glucocorticoids most notably act during late gestation to stimulate surfactant production by the lung. This action is critical to prepare the fetus for extrauterine life, and it is for this reason that synthetic glucocorticoid treatment is so widely used in preterm pregnancies where lung immaturity threatens neonatal viability. Although these treatments greatly improve survival [3], they are not without adverse effects.

Glucocorticoids regulate many of the processes required for successful embryo implantation, as well as for the subsequent growth and development of the fetus and placenta. In utero, the endometrium, placenta and embryo/fetus are each exposed to physiological glucocorticoids arising from either maternal or fetal adrenal glands. It has been shown that glucocorticoids have several roles in improving the intrauterine environment. For example, in uterus, glucocorticoids regulate the synthesis of prostaglandins that have been implicated to play critical roles during implantation by increasing stromal vascular permeability [4] and in the initiation of parturition [5]. The periimplantation secretion of human chorionic gonadotrophin (hCG) from human term trophoblasts can be stimulated by up to 10 -fold by treatment for 24 to $72 \mathrm{~h}$ with synthetic 
glucocorticoids dexamethasone and triamcinolone [6, 7]. Glucocorticoids have several antiinflammatory actions required for implantation. In first trimester human cytotrophoblasts, cortisol can suppress the synthesis of the pro-inflammatory interleukin (IL)-1b [8]. Similarly, in term human placental cytotrophoblasts, physiological concentrations of cortisol and numerous synthetic glucocorticoids can inhibit secretion of pro-inflammatory cytokines tumor necrosis factor (TNF)- $\alpha$, IL-6 and IL-8 without affecting the expression of antiinflammatory cytokine IL-10 [9-11]. Glucocorticoids contribute to preventing immunological rejection of the fetal semiallograft in the pregnant uterus by inhibiting eosinophil infiltration [12]. Moreover, glucocorticoids profoundly and specifically suppress expression of fibronectin and laminin, two extracellular matrix proteins that are important mediators of uterine-placental adherence [6].

Furthermore, glucocorticoids activate many of the biochemical processes in these tissues such as altering expression of numerous receptors, enzymes, ion channels, transporters, growth factors, cytoskeleton proteins, binding proteins, clotting factors, gap and tight junction proteins and intracellular signaling pathways' components involved in growth. Taken together, these glucocorticoid-induced changes in cell physiology combine to produce functional alterations at the systemic level [13].

In pregnancy, glucocorticoid administration is used mainly in the management of women at risk of preterm labor and in the antenatal treatment of fetuses at risk of congenital adrenal hyperplasia. It is recommended that, for pregnant women who are at risk of preterm delivery within 7 days between 24 weeks and 34 weeks of gestation, a single course of corticosteroid administration should be performed. And a single course of antenatal corticoids should be administered to women with premature rupture of membranes before 32 weeks gestation to reduce the risks of respiratory distress syndrome, perinatal mortality and other morbidities [14]. Numerous evidence indicates that increased exposure of the fetus to glucocorticoids in mid- to late pregnancy may result in adverse outcomes including intrauterine growth restriction (IUGR) [15-18], postnatal hypertension $[15,19]$, postnatal cardiovascular disease [20], postnatal glucose intolerance [20], increased postnatal activity in the hypothalamo-pituitary-adrenal axis [21-24], effects on fetal brain development [21, 25, 26].

Glucocorticoid actions within the cell are regulated by Glucocorticoid Receptor (GR) [27]. On hormone binding, activated GR translocates from the cytoplasm to the nucleus as a dimer to associate with specific DNA sequences termed glucocorticoid response elements (GREs) and acts as a ligand-dependent transcription factor [28]. GR-mediated transcriptional activation is modulated by phosphorylation [29]. GRs are highly expressed in decidua, chorion, amnion, stromal fibroblasts, vascular smooth muscle cells and endothelial cells of human term placentas, with moderate expression in cytotrophoblasts and negligible expression in syncytiotrophoblast [30-34]. Because the significance of glucocorticoids to the early mammalian embryo is clear and glucocorticoid action within the cell is regulated by GR, we investigated GR expression during the course of rat embryogenesis until day 12 of gestation. The demonstrated ontogenetic pattern of GR expression indicates the potential 
sites of biological action of the glucocorticoids, providing supportive evidence for its critical importance during the course of embryogenesis in rats [35].

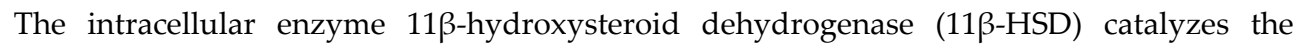
interconversion of bioactive glucocorticoids (cortisol and corticosterone) and their inactive metabolites (cortisone and 11-dehydrocorticosterone). Thus, it is an important modulator of glucocorticoid bioavailability in both glucocorticoid and mineralocorticoid target organs

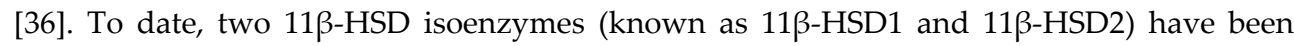
identified, characterized and cloned [37]. The conversion of cortisone to active cortisol is catalyzed by $11 \beta-H S D 1$, whereas the metabolism of cortisol to cortisone is mediated via both $11 \beta$-HSD1 and 11 $\beta$-HSD2 [38]. In placenta, $11 \beta$-HSD1 protein is expressed specifically in the placental villous endothelial cells, amnion, chorionic and extravillous trophoblasts (EVTs). $11 \beta$-HSD1 expression increases throughout pregnancy in response to progesterone [39]. As the placenta differentiates, there is an up-regulation in the expression of $11 \beta$-HSD2 enzyme that becomes the major placental isoenzyme [40]. 11 $\beta-H S D 2$ protein is localized exclusively in the syncytiotrophoblast and invasive extravillous trophoblasts with no expression in the chorion or amnion [41-43]. The distinct pattern of $11 \beta-H S D 1$ and -2 localizations may indicate having different physiological functions. In normal pregnancy, maternal glucocorticoid levels are markedly higher than those in the fetal circulation. It has been stated that the role of placental $11 \beta-H S D$ is to protect the fetus from adverse effects of maternal glucocorticoids. 11 $\beta$-HSD2 is better suitable for this role because of its location (the site of maternal-fetal exchange) and its enzymatic properties (higher affinity for cortisol). This enzyme acts as a 'barrier' to prevent premature or inappropriate action at glucocorticoid-responsive tissues during fetal development [44]. It has been suggested that a reduction in the expression or activity of placental $11 \beta-H S D 2$, by leading to increased transplacental passage of active glucocorticoids, reduces fetal growth. 11/-HSD2 knockout (11 $\beta$-HSD2-/-) mice exhibit reduced birth weight and heightened anxiety in adulthood [45]. Numerous studies have shown that inhibition of $11 \beta-\mathrm{HSD} 2$ during pregnancy leads to a reduction in birth weight and the development of later hypertension and glucose intolerance [46-48], as well as programming increased HPA axis activity and anxiety-related behaviors [49]. Moreover, placentas from 11 $\beta$-HSD2 knockout mice fetuses have impaired labyrinth zone capillary development accompanied by a decline in vascular endothelial growth factor (VEGF)-A mRNA expression and altered transport of nutrients by system A amino acid transporter (SNAT) [50]. Furthermore, a correlation between decreased activity of $11 \beta$-HSD2 in the human placenta and IUGR has been reported [15, 51, 52]. In addition, mutations in the HSD11B2 gene in humans, although rare, markedly reduce birth weight [53]. It was found that while maternal administration of glucocorticoids caused IUGR, glucocorticoid administration directly into the fetal circulation did not restrict fetal growth, which suggests that the growth limiting effects of glucocorticoids are mediated via actions in the utero-placental unit rather than effects on fetal tissues [54]

Placental development is a critical determinant of fetal growth and glucocorticoids affect growth and development of the fetus indirectly by affecting placental development and function. The actions of glucocorticoids on fetal growth are mediated, in part, by changes in 
the placenta. In sheep, rats, mice and non-human primates, administration of synthetic glucocorticoids during late gestation reduces placental weight. In most of these species, the effect of glucocorticoids on the placenta is greater than that on the fetus [13]. Glucocorticoids have been implicated in the fusion of cytotrophoblast cells to form the syncytiotrophoblast and associated with morphological (accelerated apical microvilli formation, nuclear maturation, and increase in cell organelle number) and functional (elevated hCG secretion and increased 11 $\beta$-HSD2 mRNA expression) markers of syncytiotrophoblast differentiation. These findings suggest that glucocorticoids stimulate syncytiotrophoblast differentiation and maturation [55-57].

Microarray analysis showed that maternal glucocorticoid administration leads to marked changes in the gene expression profile in the placenta. Dexamethasone (Dex) caused a decrease in expression of genes involved in cell division such as cyclins A2, B1, D2, CDK 2, CDK 4 and M-phase protein kinase along with growth-promoting genes such as epidermal growth factor receptor, bone morphogenetic protein 4 and insulin-like growth factorbinding protein 3. In addition, Dex treatment led to down-regulation of genes involved in protein biosynthesis, skeletal development, and collagen metabolism. There was also decreased expression of genes involved in cell division, DNA replication, chromosome segregation, DNA alkylation, nucleotide and nucleoside biosynthesis, microtubule-based processes, B-cell activation and differentiation processes, innate immune response, antigen processing and presentation, and complement system [58]. Treatment of rats with glucocorticoids restricts placental vascular development via inhibition of the VEGF-A and peroxisome proliferator-activated receptor $\gamma(\operatorname{PPAR} \gamma)$ which is regulated by VEGF-A expression $[59,60]$. In addition, in response to glucocorticoid treatment of either the mother or fetus, there are changes in the placental handling of certain amino acids such as alanine, glutamine and glutamate. However, there have been few studies on the effects of glucocorticoids on amino acid transporters in the placenta of any species to date [61, 62]. Additionally, glucocorticoids change the production and metabolism of hormones by the placenta such as prostaglandins, placental lactogen, leptin, corticotrophin-releasing hormone (CRH), estrogens, progesterone and other progestagens [63, 64]. Glucocorticoids also alter the placental activity of various enzymes involved in the synthesis and inactivation of steroids and thyroid hormones such as 17,20-lyase, 17 $\alpha$-hydroxylase, aromatase, renin and endothelial nitric oxide synthase [63].

\section{The effects of glucocorticoids on placental cell cycle}

Glucocorticoids play a fundamental role in pregnancy with effects on decidualization, implantation, placental development, fetal brain development, lung maturation and parturition but fetal-placental exposure to maternally administered glucocorticoids may lead to abnormalities of fetal and placental growth [15, 19, 65]. The mode of action of glucocorticoids in placental growth inhibition has not been determined.

Human placental development is established by trophoblast invasion into the uterine endometrium and its vasculature. The resulting changes will facilitate an increase in 
intervillous blood flow and, hence, the exchange of nutrients and molecules between maternal and fetal blood. The transports as well as metabolic and endocrine functions of the placenta reside primarily in the floating villi covered by the syncytiotrophoblast, a tissue that results from terminal differentiation of underlying villous cytotrophoblasts and their subsequent fusion. Anchoring villi establish physical connection of the placenta with the decidua predominantly by a subpopulation of cytotrophoblasts known as EVT. They accumulate at the tips of the anchoring villi and form cell columns. Both villous and extravillous cytotrophoblast subpopulations arise by proliferation and differentiation from stem cells located within the cytotrophoblast layer of the chorionic villi [66].

On the basis of the immunostaining of the Ki67 antigen, a cell cycle regulator with yet unknown role, EVTs have been categorized as the proliferative phenotype, which is primarily located in the proximal part, and the invasive phenotype that is located mainly in the distal part of cell columns [66]. Current understanding assumes that EVT can differentiate, thereby acquiring an invasive phenotype, which eventually enables them to invade the maternal decidua and spiral arteries. Thus placental development involves proliferation and differentiation of the cytotrophoblasts in a manner that is tightly regulated in time and space.

Eukaryotic cell cycle consists of four phases, G1, S, G2 and M. G1 and G2 are preparation phases for DNA synthesis (S) and mitosis (M) phases respectively. During G1 and G2 phases cell growth, doubling of the amount of protein and organelles and preparation for the next phase occurs. If the conditions are not appropriate, cells in G1 phase stop cell cycle progression and enter into a resting state, known as G0 phase, where they continue biological functions but do not go through the rest of the cell cycle. When growth signals are received, cells in G0 phase can continue the cycle through the G1 phase [67, 68].

The eukaryotic cell cycle is regulated by the coordinated activity of a family of cyclindependent kinases (CDKs). These are positively and negatively regulated by the cyclin and CDK inhibitor families [69, 70]. Based on the timing of their appearance in the cell cycle, cyclins can be divided into two groups, i.e. the mitotic cyclins A and B and the G1 cyclins of the D and E families [71]. Cyclin A promotes both G1/S and G2/M transitions, whereas cyclin B1 accumulates in the cytosol during late S phase and G2 and enters the nucleus at the onset of mitosis [72].

In mammalian cells, there are at least two distinct families of CDK inhibitors: the INK4 and the Cip/Kip inhibitors (p21, p27, p57). Both families play regulatory roles during the G1/S cell cycle checkpoint [73]. Because of their broader panel of CDKs with which they interact [74], the inhibitors of the Cip/Kip family control other checkpoints as well. p21 plays a role during the G2/M phase transition [75] and may also mediate $S$ phase [76] and G2 arrest [77]. Overall it is correlated with cell cycle arrest before terminal differentiation [78]. Also, p27 has the capacity to arrest cells in G2 [77]. p57 inhibits cyclin A- and E-associated CDKs and therefore regulates G1/S transition and completion of $S$ phase [79] and is primarily expressed in terminally differentiated cells [80]. 
Despite the importance in understanding the mechanisms controlling proliferation, little is known about how cytotrophoblast proliferation is coordinated with differentiation and what factors determine whether cytotrophoblast cells divide or differentiate and syncytialize. A few studies localized cell cycle regulators that are specifically expressed during key transitions and phases [81-83].

The hypothesis that the coordinated expression of cell cycle progression and inhibition factors will determine whether cytotrophoblasts proliferate or undergo cell cycle arrest or cell cycle exit allowing subsequent differentiation was tested by our team. The cell cycle promoters cyclin A, cyclin B1, proliferating cell nuclear antigen (PCNA), Ki67 and the cell cycle inhibitors p21, p27 and p57 were immunolocalized in tissue sections of first trimester pregnancies (weeks 6 and 9-12). Villous cytotrophoblasts were immunolabelled for Ki67 and cyclin A but only few were stained with anti-cyclin B1. The syncytiotrophoblast was devoid of immunoreactivity for any of the cell cycle progression factors. It expressed especially p21, whereas p27 and p57 were predominantly found in villous cytotrophoblasts. PCNA, Ki67, cyclin A and cyclin B1 were immunolocalized in proximal and distal EVTs of anchoring villi and in EVT which had invaded the upper decidual segments. All EVTs strongly expressed p27 and p57, but not p21. These data clearly suggest different functions for p21, p27 and p57 in placental development with distinct roles for p21 and p57 in syncytiotrophoblast and EVT differentiation, respectively. p27 appears to be involved in both the processes. The results may also challenge the concept of differential mitotic activity in the proximal and distal parts of the first trimester cytotrophoblast cell column, but more functional studies are clearly needed. The presence of p27 and p57 in EVT cells, which invade the deciduas deeply, may account for the loss of mitogenic potential of these cells [84].

Although the architecture of the human and rodent placentas differs, their anatomical structures and molecular mechanisms have been compared $[85,86]$ and analogies drawn between the various cell types; furthermore, the molecular mechanisms of placental development are thought to be very similar between the two species. Thus, the rodent placenta is increasingly used as a model to study mechanisms underlying placental development [85, 87].

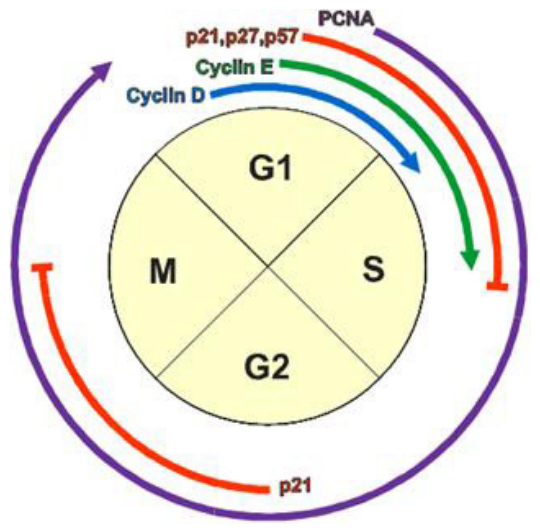

Figure 1. Schematic representation of cell cycle related proteins in rat placenta of our study [88]. 
We have been used to localize G1 cyclins (D1, D3, E), which are major determinants of proliferation, Cip/Kip inhibitors, p53 as a master regulator and proliferating cell nuclear antigen in all cell types of the rat term placenta. Schematic representation of cell cycle related proteins studied is showed in Figure 1. The proportion of each cell type immunolabeled was counted. Cyclin D1 and cyclin D3 were present mostly in cells of the fetal aspect of the placenta, whereas the G1/S cyclin E was present only in the spongio- and labyrinthine trophoblast populations. Among the Cip/Kip inhibitors, p21 was present only in cells of the fetal aspect whereas p27 and p57 were found in all cell types studied. p53 was only found in a small proportion of cells with no co-localization of p53 and p21 [88]. Schematic representation of our immunohistochemistry results in the rat placenta is showed in Figure 2. The data suggest that the cells of the fetal side of the rat placenta still have some proliferation potential which is kept in check by expression of the Cip/Kip cell cycle inhibitors, whereas cells of the maternal aspect have lost this potential. Apoptosis is only marginal in the term rat placenta. In conclusion, proliferation and apoptosis in rat placental cells appears controlled mostly by the Cip/Kip inhibitors in late pregnancy. It is still not known how coordination mechanisms of proliferation and differentiation are influenced by glucocorticoid induced IUGR in the placenta.

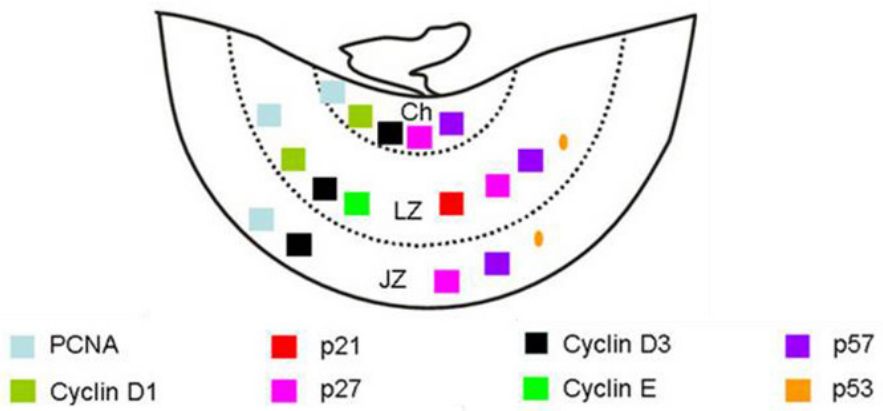

Ch: Chorion, LZ: Labyrinth Zone (fetal placenta), JZ: Junctional Zone (maternal placenta) [88].

Figure 2. Schematic representation of our immunohistochemistry results in the rat placenta.

We aimed to investigate the effects of maternally administered synthetic glucocorticoid Dex on cell proliferation, cell cycle arrest or apoptosis of placental development. We investigated the spatial and temporal immunolocalization of PCNA, Ki67, p27 and p57 in normal and Dex-induced IUGR placental development in pregnant rats. PCNA immunolabeling intensity in placentas of the control group was statistically significantly higher than that in the Dexinduced IUGR group placentas on all days in junctional and labyrinth zones (JZ and LZ, respectively). We observed decreased Ki67 staining intensity in the labyrinth trophoblasts of Dex-induced IUGR placentas compared to controls on day 21. Ki67 immunolabeling intensity was higher in the control group than that in the IUGR group placentas on all days in both zones except for day 21 in the junctional zone. These differences were statistically significant on days 15, 17 and 19 in the junctional zone and on days 13, 15, 17 and 21 in the labyrinth zone. Ki67 staining intensity decreased gradually after day 15 in both zones of control and 
IUGR placentas. Ki67 immunostaining intensities were stronger in the labyrinth zone compared to the junctional zone in both groups. Moreover, after day 17, scarcely any Ki67 immunostaining was obtained in the IUGR placentas in the junctional zone. We found stronger p27 immunolabeling intensity in Dex-induced IUGR placentas when compared to control placentas in both junctional and labyrinth zones for all gestational days (Table 1) [89]. In accordance with this, in another study, it was observed that in the Dex-induced human choriocarcinoma JEG-3 cells p27 mRNAs were upregulated [90]. We observed that p57 immunostaining intensities in Dex-induced IUGR placentas were stronger compared to controls in both zones for all gestational days. We found that Dex-induction results in p57 upregulation in rat placental development [89]. In contrast to our results, p57 was not expressed in Dex-induced JEG-3 cells [90]. In another study, we wanted to determine the Ser/Thr protein kinase Akt and a MAPK (Mitogen-Activated Protein Kinase) ERK1/2 related proliferation and apoptosis mechanisms are influenced by Dex-induced IUGR placentas. Thus, we investigated the expression levels and spatio-temporal immunolocalization of Akt, p-Akt, ERK1/2 and p-ERK1/2 proteins in normal and Dex treated placental development of rats. We found that maternal Dex treatment led to a decrease in ERK1/2 and Akt activation during rat placental development together with placental and fetal weight loss. Akt activation was significant at junctional zones of the rat placenta, especially at spongiotrophoblast cells and giant cells, and reduced after dexamethasone treatment. On the other hand, ERK1/2 activation was seen in both junctional and labyrinth zones of the rat placentas and was weaker in labyrinth zones of IUGR group placentas. The decrease in ERK1/2 and Akt activation may result in cell survival inhibition or apoptosis stimulation. Consequently, Dex induced placental and embryonal developmental abnormalities could be associated with reduction of Akt and ERK1/2 activation [91]. In another study, decreased levels of placental Akt phosphorylation was observed after in utero exposure to Dex [92].

Antenatal Dex use is associated with reduction in fetal and placental weight with morphological changes in the placenta. Dex-treated mouse placentas showed swollen trophoblast cells in both the junctional and labyrinth zones and increased apoptosis of trophoblast cells in the junctional zone. Moreover, Dex-treated placentas were hydropic, friable and pale [58]. Increasing antenatal corticosteroid exposure was associated with villous fibrosis, stromal mineralization, and less frequent villous infarction [93]. In addition, treatment with Dex prevented the normal rise in VEGF expression and the associated increase in labyrinthine vascularity over the final third of pregnancy. Therefore, Dex appears to reduce labyrinth zone growth by preventing the normal development of the fetal vasculature within the labyrinth zone [59]. Moreover, microarray analysis showed that Dex caused a decrease in expression of genes involved in cell division such as cyclins A2, B1, D2, CDK 2, CDK 4 and M-phase protein kinase along with growth-promoting genes such as epidermal growth factor receptor, bone morphogenetic protein 4 and insulin-like growth factor-binding protein 3 [58]. In addition, 3H-thymidine incorporation assay revealed that proliferation of trophoblast cell lines JEG-3 and HTR-8/SV neo and human first-trimester primary trophoblasts was time- and dose-dependently inhibited by glucocorticoids [94]. Impaired growth in Dex-treated placentas was also characterized by decreased expression of 
both prolactin-like protein-B and insulin-like growth factor (IGF)-II, particularly in the junctional zone of the rat placenta [92]. Dex-treatment increased apoptosis of trophoblast cells in mouse and rat placentas. Dex-induced trophoblast apoptosis was mediated through activation of caspases 1 and $3[58,95]$. Apoptosis was also induced in primary cultures of third trimester human decidual cells when treated with cortisol, cortisone, or dexamethasone [34]. Likewise, Dex was shown to induce both apoptosis and necrosis in primary cultures of term human placental trophoblast, in an in vitro model of syncytialization and in the SGH-PL4 cell line derived from human extravillous trophoblasts by measuring the cytokines TNF-alpha and IFN-gamma using the TUNEL technique, Annexin V binding, fluorescence microscopy and ATP/ADP measurements [96]. In another study, using a human in vitro term placental explant model, Dex treatment was shown to be associated with morphological (accelerated apical microvilli formation, nuclear maturation,

\begin{tabular}{|c|c|c|c|}
\hline $\begin{array}{c}\text { Gestational } \\
\text { days }\end{array}$ & $\begin{array}{c}\text { Junctional } \\
\text { Zone } \\
\end{array}$ & $\begin{array}{c}\text { Labyrinth } \\
\text { Zone } \\
\end{array}$ & $\begin{array}{c}\text { Cell cycle } \\
\text { protein }\end{array}$ \\
\hline 13 & $\downarrow$ & $\downarrow$ & \multirow{5}{*}{ PCNA } \\
\hline 15 & $\downarrow$ & $\downarrow$ & \\
\hline 17 & $\downarrow$ & $\downarrow$ & \\
\hline 19 & $\downarrow$ & $\downarrow$ & \\
\hline 21 & $\downarrow$ & $\downarrow$ & \\
\hline 13 & - & $\downarrow$ & \multirow{5}{*}{ Ki67 } \\
\hline 15 & $\downarrow$ & $\downarrow$ & \\
\hline 17 & $\downarrow$ & $\downarrow$ & \\
\hline 19 & $\downarrow$ & - & \\
\hline 21 & - & $\downarrow$ & \\
\hline & & & \multirow{6}{*}{ p27 } \\
\hline 13 & $\uparrow$ & $\uparrow$ & \\
\hline 15 & $\uparrow$ & $\uparrow$ & \\
\hline 17 & $\uparrow$ & $\uparrow$ & \\
\hline 19 & - & $\uparrow$ & \\
\hline 21 & $\uparrow$ & $\uparrow$ & \\
\hline & & & \\
\hline 13 & $\uparrow$ & - & \multirow{5}{*}{ p57 } \\
\hline 15 & $\uparrow$ & $\uparrow$ & \\
\hline 17 & $\uparrow$ & $\uparrow$ & \\
\hline 19 & - & - & \\
\hline 21 & $\uparrow$ & $\uparrow$ & \\
\hline
\end{tabular}

Table 1. Immunolabeling intensity changes of PCNA, Ki67, p27 and p57 in the junctional and labyrinth zones of placentas of the IUGR group rat placentas compared to control of given gestational day $(p=<0.05)$. - , statistically significantly unchanged; $\uparrow$, statistically significantly increased; $\downarrow$, statistically significantly decreased. 
and increased cell organelle number) and functional (elevated hCG secretion, increased 11ßHSD2 mRNA expression and reduced cytotrophoblast proliferation markers) of syncytiotrophoblast differentiation. These findings suggest that Dex stimulates syncytiotrophoblast differentiation and maturation [57]. In another study, BeWo and JEG-3 choriocarcinoma cell lines used as models for human trophoblast were cultured with another synthetic glucocorticoid triamcinolone acetonide (TA). TA altered the number of viable and dead cells as well as cyclin B1 expression levels shown by Western blotting and to a lesser extent, invasion of BeWo and JEG-3 cell lines determined by Matrigel invasion assay and by measuring the secretion (ELISA) of matrix-metalloproteinases (MMP-2, MMP-9) [97].

\section{The effects of glucocorticoids on fetal and placental angiogenesis mechanisms}

Angiogenesis is a complex process that may be initiated by a large number of stimuli and that is performed through multiple biologic pathways and a variety of molecules. With the increased understanding of angiogenesis, it has become clear that many of its pathways are parallel and redundant, greatly complicating efforts to interrupt the process. The disruption of one pathway most likely does not abolish completely the formation of new blood vessels, which may explain the less than perfect clinical results achieved when treating neovascular processes with currently available regimens. Combination therapies and drugs that target more than one pathway have become more popular and intensively explored.

Angiogenesis is required for the cyclic processes of endometrial growth, breakdown, and repair during the menstrual cycle, and it provides a richly vascularized tissue receptive for implantation and placentation [98]. Besides, the formation of new blood vessels is essential for organogenesis and successful embryonic and fetal development.

For many years glucocorticoids have been used in pregnant women for several reasons such as risk of premature deliveries or treatment of a variety of medical disorders like bronchial asthma, systemic lupus erythematosous etc.. The dosages and types of glucocorticoids changes depending on the severity of the symptoms and treatment procedure [99].

It is reviewed by Hadoka et al. [100] that endogenous GCs contribute to physiological angiogenesis mechanisms by regulating the new vessel formation processes. Endothelial cells are seem to be a target of glucocorticoid effect as they both express glucocorticoid and mineralocorticoid receptors [101, 102]. But overexposure to glucocorticoids during pregnancy has adverse effects on placental angiogenesis mechanisms. Therefore these steroids should be carefully used in pregnancy.

Hewitt et al. [59] investigated the impact of increased glucocorticoid exposure on the spatial and temporal expression of the endothelial cell-specific mitogen; VEGF and associated placental vascularization over the final third of rat pregnancy. They showed that treatment with dexamethasone prevented the normal rise in VEGF expression as a LZ specific manner. Their data suggest that glucocorticoid induced restriction of fetal and placental growth is mediated, in part, via inhibition of placental VEGF expression and associated reduction in 
placental vascularization. Therefore, dexamethasone appears to reduce LZ growth by preventing the normal development of the fetal vasculature within the LZ.

As it is mentioned in the study above, GCs have adverse effect on placental angiogenesis mechanisms. This effect would be related with both angiogenic activity of the endothelial cells or maybe related with proliferation or cell survival processes. It was reported in a previous study that GCs inhibit tube formation of cultured endothelial cells [103] but the molecular mechanisms underlying this effect hasn't been clearly understood [104].

Recently, Logie et al. [105] reported that GCs do not affect the endothelial cell viability or proliferation but tube formation capacity. This investigation addressed the hypothesis that the potent antiangiogenic action of glucocorticoids is due to prevention of tube formation by endothelial cells. Cultured human umbilical vein endothelial cells (HUVEC) and aortic endothelial cells (HAoEC) were used to determine the influence of glucocorticoids on tubelike structure (TLS) formation, and on cellular proliferation, viability and migration. Dexamethasone or cortisol (at physiological concentrations) inhibited both basal and prostaglandinF-2 $\alpha$-induced and VEGF stimulated TLS formation in endothelial cells cultured on Matrigel, effects which were blocked with the glucocorticoid receptor antagonist RU38486. Glucocorticoids had no effect on endothelial cell viability, migration or proliferation. Time-lapse imaging showed that cortisol blocked VEGF-stimulated cytoskeletal reorganization and initialization of tube formation. Exposure to glucocorticoids reduced the formation of cell-cell contacts rather than increasing degradation of existing tubes. They concluded that glucocorticoids interact directly with glucocorticoid receptors on vascular endothelial cells (ECs) to inhibit TLS formation. This action, which was conserved in ECs from two distinct vascular territories, was due to alterations in cell morphology rather than inhibition of EC viability, migration or proliferation. These findings provide important insights into the anti angiogenic action of endogenous glucocorticoids in health and disease [105].

According to the results of an ongoing study of us, Triamcinolone treatment decreased VEGF expression in HUVECs. In this study, we tested the hypothesis that IUGR could be observed in fetuses as a result of insufficient nutrient transport depending on the glucocorticoid effect on placental angiogenesis mechanism that leads to inadequate vessel development. HUVECs were cultured at different concentrations $(0.5,5,50 \mu \mathrm{mol} / \mathrm{L})$ of the synthetic glucocorticoid triamnicinolone acetonide for 48 and 72 hours. After culture, RTPCR, ELISA, Western blot and Matrigel experiments were performed. On the other hand, dexamethasone was injected to rats during gestation. Placenta and blood samples were taken from rats on gestational days 14, 16, 18 and 20. RT-PCR and Western blot analyses were performed on placentas while ELISA test was applied to sera and HUVEC culture media. We found that in HUVECs; VEGF, VEGFR1, VEGFR2, Placental Growth Factor (PIGF) and Fibroblast Growth Factor (FGF) gene levels on 48 and 72 hours decreased in 50 mM TA groups compared to control. VEGF protein amount on 48 and 72 hours decreased in TA groups compared to control. VEGFR1 protein quantity decreased and VEGFR2 
protein quantity increased in a dose- and time-dependent manner. According to ELISA results, VEGFR1 secreted by HUVEC cells decreased while VEGFR2 and FGF increased. In Matrigel experiments, decreased vessel tube structures were created by HUVEC cells exposed for 72 hours to $50 \mathrm{mM}$ TA. The amount of VEGF in Dex treated rat sera statistically significantly decreased on days 14,16 and 20, while there is no difference on day 18 compared to control. VEGF protein amount showed a decrease in all gestational days of IUGR group compared to control in rat placentas. VEGFR1 decreased in advancing pregnancy days of control group while increased in parallel to pregnancy days of IUGR group. VEGF and VEGFR1 gene level was lower at term rat placentas compared to control group at gestational day 20. In conclusion our results showed that glucocorticoids had a negative effect on angiogenesis mechanism (Figure 3) via altering the angiogenesis related protein and gene expression, and tube formation capacity and angiogenesis related proteins in sera (A.Ozmen, G.Unek, D.K. Korgun, I.Mendilcioğlu and E.T.Korgun unpublished).

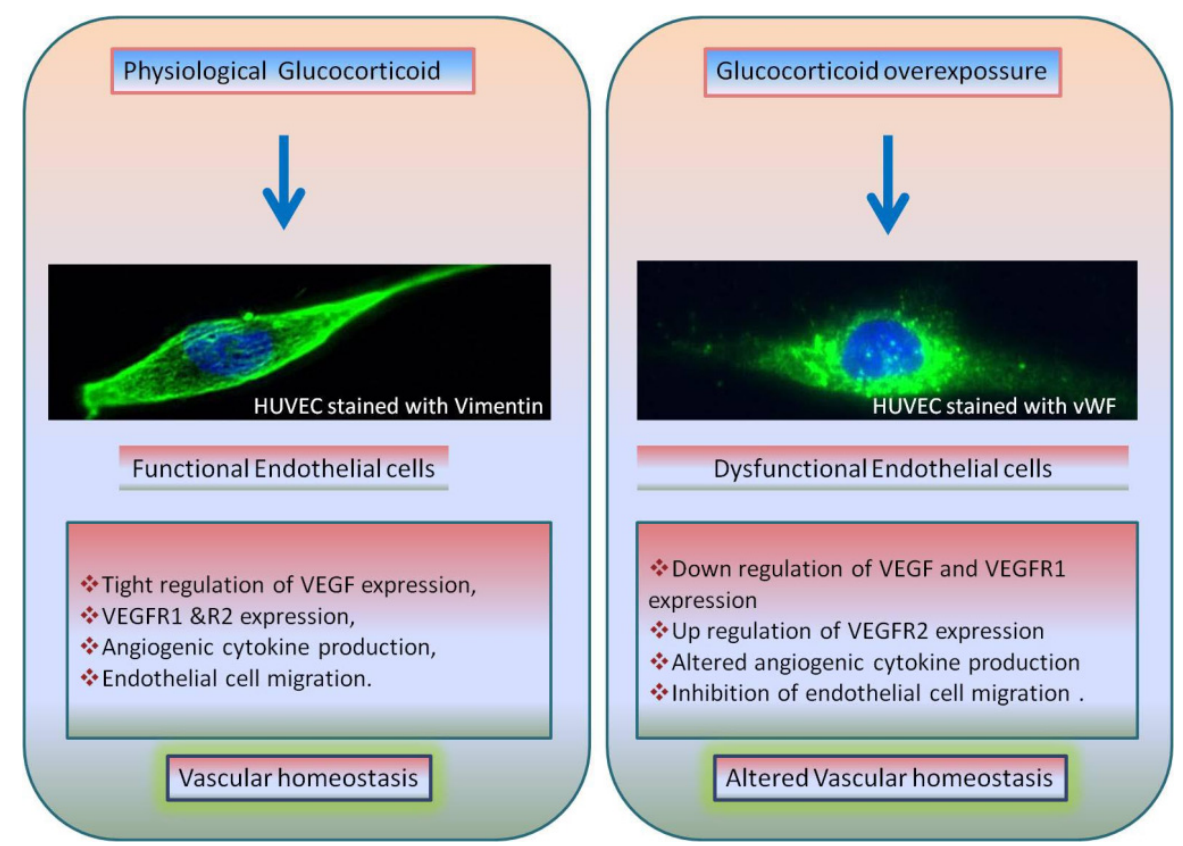

Figure 3. A possible model for glucocorticoid effect on endothelial cells. In physiological conditions; in the case of moderate GC concentrations (left picture), vascular homeostasis is tightly regulated. VEGF, VEGFR1\&R2 expression, angiogenic cytokine production, endothelial cell migration, blood flow velocity etc... is maintained in a balance in functional endothelial cells. But when GC concentration is increased (right picture), endothelial cell are subjected to excess GC. And this GC overexposure results with endothelial dysfunction by downregulating VEGF and VEGFR1 expression, upregulating VEGFR2 expression, altering angiogenic cytokine production and by inhibiting endothelial cell migration etc... (vWF: Von Willebrand Factor) 
In another study of ours, we investigated the effects of glucocorticoids on rat placental development depending on the PI3K/Akt and MAPK-ERK1/2 pathways [91]. It was observed that, the IUGR group had significantly smaller embryos on day 20 of gestation and had smaller placentas on day 14, 16, 18 and 20 compared with control. Maternal dexamethasone treatment led to a significant decrease in Akt activation on day 16, 18, and 20. Total Akt protein expression was not significantly affected by the treatment. There was a significant decrease in ERK1/2 activation on day 18 in IUGR group; on the other hand there was a significant increase on day 16. Total ERK1/2 protein expression didn't show any significant difference between groups. We observed that phospho-Akt immunolabelings were remarkable in junctional zone in control groups and weaker in IUGR groups. Phospho-ERK1/2 immunolabelings were considerable in the junctional and labyrinth zones in the control groups and weaker in IUGR groups. We found that ERK1/2 activity was decreased in the dexamethasone treated IUGR groups. This decrease was especially seen in the LZ of the rat placenta. Concerning the importance of Erk $1 / 2$ on placental vasculature development [106-109], it could be said that the decrease in ERK1/2 activity might be related with vascular failure and this could result with abnormal placental development. Besides it is mentioned in the literature that the PI3K/Akt pathway modulates the expression of some angiogenic factors such as nitric oxide and angiopoietins. Numerous inhibitors targeting the PI3K/Akt pathway have been developed, and these agents have been shown to decrease VEGF secretion and angiogenesis. [110]. Therefore, dexamethasone induced decreased Akt phosphorylation may negatively affect the placental angiogenesis mechanisms. There are some other studies [111, 112] mentioning the effect of GCs on fetal/placental vasculature during pregnancy. These studies report that GCs alter the physiological condition of the vasculature and leads pathological conditions. Aida et al. [111] determined a significant depression of total placental eNOS protein measured by ELISA (betamethasone treated vs control) and immunohistochemistry in both syncytiotrophoblast and vascular endothelium. In conclusion, maternally administered betamethasone produces a consistent decrease in several indices of placental eNOS function that may play a role in the altered cardiovascular dynamics and fetal growth retardation produced by betamethasone administration in late pregnancy.

Angiogenesis is tightly regulated by hormones. Hormones regulate blood vessel growth by controlling the production of local chemical mediators, often other hormones, but also growth factors, cytokines, enzymes, receptors, adhesion molecules, and metabolic factors. As mentioned above, GCs may show their effects directly on endothelial cells or indirectly for example by altering cytokine production that may affect placental vasculature. $\mathrm{Xu}$ et al. 2005, [9] studied the effects of GCs on placental cytokine production. Villous explants were cultured with increasing concentrations of glucocorticoids (betamethasone and methylprednisolone, $0.0025 \mathrm{mM}, 0.25 \mathrm{mM}$ and $25 \mathrm{mM}$ ). The dose effect of glucocorticoids on cytokine (TNF- $\alpha$, IL-6 and IL-10) production was examined using ELISA. There was a stepwise reduction of TNF- $\alpha$ and IL- 6 with increasing doses of betamethasone and methylprednisolone from placentas of women with preeclampsia and normal pregnancy. 
However, IL-10 was not altered in conditioned medium by increasing doses of glucocorticoids. In pregnancy, TNF- $\alpha$ can cause direct damage to endothelial cells, increase endothelial cell permeability, up-regulate endothelial adhesion molecules (ICAM-1, VCAM-1, E-Selectin) and promote vasoconstriction, all of which are identified in the pathogenesis of preeclampsia [113]. IL-10 is an immunosuppressive Th2-type cytokine which is produced by immune cells including T-cells, monocytes, macrophages, granulocytes and NK cells and also trophoblasts. IL-10 has been also shown to be a potent inhibitor of Th1 cell proliferation and the production of Th1-type cytokines such as TNF- $\alpha$ [114].

To observe the influence of maternal betamethasone administration for fetal lung maturation on the arterial, venous and intracardiac blood flow of the fetus and the uterine arteries; twenty-seven women with singleton pregnancies were examined before the first, and $30 \mathrm{~min}$ and $8,24,48$ and $72 \mathrm{~h}$ after the second of two single doses of $8 \mathrm{mg}$ of betamethasone. The blood flow velocity waveforms of the umbilical artery (UA), the middle cerebral artery, the uterine arteries, the ductus venosus, the inferior vena cava and the right hepatic vein, the pulmonary trunk, the ductus arteriosus and the right and left intraventricular inflow of the heart was recorded. The resistance index of the UA showed a significant transient decrease $30 \mathrm{~min}$ after the second betamethasone dose. The peak systolic velocity of the ductus arteriosus increased significantly $30 \mathrm{~min}$ after the 2nd dose and then returned to non-significant values. No significant change was observed in any of the other vessels. So it could be said that Betamethasone causes short-term changes in fetal blood flow. However, this effect seems to be mild and reversible and does not appear to contraindicate the use of corticosteroids to promote fetal lung maturation [115]. Therefore, it could be mentioned that long term dexamethasone usage my result with decreased maternal blood velocity which would negatively affect angiogenesis mechanisms as maternal blood itself contains angiogenesis related proteins.

It is reviewed by Oliver et al. [116] that corticosteroids are believed to act at multiple levels of angiogenesis by regulating growth factors, proteases, and blood cell behavior, and have shown significant promise in clinical studies of neovascularization secondary to diabetes, age-related macular degeneration (AMD), and ocular histoplasmosis syndrome [117-121]. Angiostatic steroids have been proposed to inhibit angiogenesis by altering the capillary basement membrane composition, suppressing its dissolution, and inhibiting endothelial cell migration, in addition to their capacity of regulating the participation of inflammatory cells in the neovascular process [122-124]. There is a growing body of evidence that reports inhibitive effects of glucocorticoids on angiogenesis mechanisms [105, 125-128] but there is limited data about the impact of glucocorticoids on placental angiogenesis mechanisms. Glucocorticoid-mediated inhibition of angiogenesis is important in physiology, pathophysiology and therapy. However, the mechanisms through which glucocorticoids inhibit growth of new blood vessels have not been established. Over-exposure to GCs may alter intracellular signaling pathways such as MAPK/ERK1/2 and PI3K/Akt with a processes mediated by GR and finally expression of angiogenic proteins could be altered (Figure 4). 


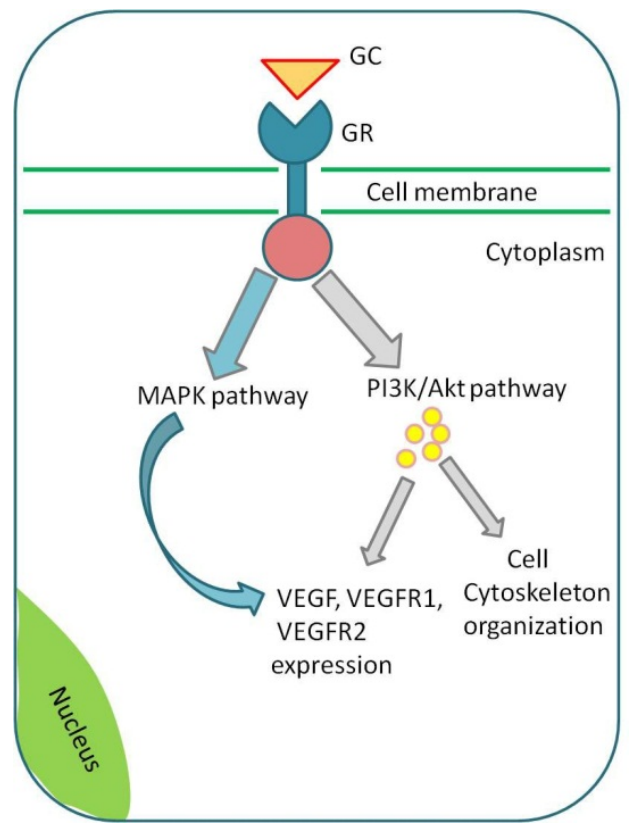

Figure 4. Glucocorticoids might show their effects on angiogenesis mechanisms by altering intracellular signal transduction pathways. GCs affect cellular processes via binding Glucocorticoid receptor. MAPK and PI3K/Akt (by phosphorylation of several downstream molecules; yellow dots in the picture) pathways mediate GC action on placental angiogenesis mechanisms like VEGF, VEGFR1\&2 expression and endothelial cell cytoskeleton organization etc... (GC; Glucocorticoid, GR; Glucocorticoid Receptor)

\section{The effects of glucocorticoids on placental glucose transporters}

The Glut protein family belongs to the Major Facilitator Superfamily (MFS) of membrane transporters [129]. Most Glut proteins catalyze the facilitative (energy-independent) bidirectional transfer of their substrates across membranes. Up to now, 14 functional mammalian-facilitated hexose carriers (GLUTs) have been characterized by molecular cloning [130]. The Glut family members can be grouped into three (Class I, Class II and Class III) different classes based on their sequence similarities [131]. The isoforms GLUT1, 3 and 4 are included in Class I and represent high-affinity transport facilitators.

The existence of glucose transporters in the placenta have been known for many years. GLUT1 protein is present in placental endothelial cells [132, 133] and in the basal [132], or microvillous membranes of the syncytiotrophoblast [133-135]. GLUT3 mRNA is distributed throughout the cells of villous tissue; GLUT3 protein appears to be expressed only in the vascular endothelium and, is not expressed in the syncytiotrophoblast layer of the placenta. A strong GLUT4 signal was observed in intravillous stromal cells, appearing to co-localize with insulin receptors [136], a discovery which complements the observation of GLUT4 in fibroblasts from amnion and chorion [137]. 
GLUT proteins' cell surface expression level, greatly influences the rate of glucose uptake into the cells [131]. Uptake of glucose by the placenta is facilitated primarily by GLUT1 and in part by GLUT3 transporters [133, 138-140]. A possible major glucose transfer mechanism in the human placental villi may be depicted as follows. Glucose in the maternal bloodstream passes the apical microvillous plasma membrane of syncytiotrophoblast cells by means of GLUT1. Glucose moves through the cytoplasm of the syncytiotrophoblast by simple diffusion and leaves the cytoplasm via GLUT1 in the basal plasma membrane. GLUT1 and GLUT3 proteins contribute to the uptake of glucose by placental endothelial cells, as well as facilitate the transfer of glucose into and out of the fetal blood vessels in the villous core [133, 138-140]. About $25 \%$ of glucose entering the placenta is metabolized within this tissue; the majority of glucose is passed to the fetus through placental endothelial cells [141].

Efficient placental (maternal to fetal) transport of glucose is crucial to sustain the normal development and survival of the fetus in utero because its own glucose production is minimal [142]. The factors regulating transplacental glucose transfer are largely unknown.

In our recent study [143], we showed that Triamcinolone administration at doses of $0.5,5$ and $50 \mu \mathrm{mol} / \mathrm{L}$, led to a significant up-regulation of placental GLUT1 and GLUT3 transcripts and protein levels in Human Placental Endothelial Cells (HPECs). After several passages, the endothelial cells were cultured in the presence or absence (controls) of 0.5, 5 and $50 \mu \mathrm{mol} / \mathrm{L}$ of TA. The lower $(0.5 \mathrm{mmol})$ dose is a concentration in the lower range of doses generally used in previous cell culture studies [7] and considered comparable to the doses used to promote lung maturation in rats [144]. Other doses (5 and $50 \mathrm{mmol}$ ) were used to investigate the potentially detrimental effects of glucocorticoid excess. The highest TA dose administered to the endothelial cell cultures corresponds to the TA concentration in blood resulting after intravenous injection of a dose recommended by the manufacturers for therapy in humans. Our Western blot results showed that GC overexposure significantly increased placental GLUT1 and GLUT3 protein levels in all experimental groups of HPECs. RT-PCR analysis of placental GLUT expressions indicated that both GLUT1 and GLUT3 mRNA levels were affected by the GC induction. It was supposed that GCs caused an increase in placental GLUT proteins and mRNA expression.

The human placenta is a GC responsive organ consisting of multiple cell types including endothelial cells, fibroblasts and trophoblasts that demonstrate changes in gene expression after hormone treatment. However, little is known about the relative expression or activity of the Glucocorticoid Receptor among the various placental cell types. Previous studies have documented that placental endothelial cells expressed GR and Mineralocorticoid Receptor (MR) [101, 102] but the GR regulation of glucose transport have not been studied. We found that GR mRNA and protein expression down-regulated after 24-h cell culture of HPECs. Our results suggest that GC-mediated down-regulation of GR levels occurs through changes in protein and mRNA stability in HPECs after TA treatment. The data from the cell culture strengthens the hypothesis that increased GC levels specifically modulate GLUT expression via the GR. 
Collectively, we conclude that TA is a potent regulator of HPECs' GLUT1 and GLUT3 expression (Figure 5). This effect is mediated by GR. We speculate that GC-induced upregulation of the placental glucose transporter systems contributes to the retarded fetal and placental growth observed with GC treatment.

Similarly in a previous study [18], it is reported that exposure to excess glucocorticoids from day 15 of gestation modified rodent placental glucose transporter protein expression at day 21 of gestation in a concentration-dependent manner.

Dexamethasone treatment from day 15 to day 21 of pregnancy led to fetal hypoglycaemia. GLUT1 and GLUT3 protein expression were detectable in the rat placenta during late gestation, and dexamethasone treatment from day 15 to day 21 of pregnancy significantly decreased placental weight and up-regulated the placental protein expression of both glucose transporters during late gestation in a dosedependent manner.

Dexamethasone administration at the lower dose $(100 \mu \mathrm{g} / \mathrm{kg})$ led to modest up-regulation of placental GLUT1 protein expression, in the absence of any significant change in the protein expression of GLUT3. Dexamethasone at the higher dose $(200 \mu \mathrm{g} / \mathrm{kg})$ led to significant upregulation of the placental expression of both GLUT1 and GLUT3 in rats, with a slightly more marked effect on GLUT3 [18]. It is concluded that, depending on the dose administered, either maturational glucose transporter isoform switching might be accelerated by dexamethasone treatment during late pregnancy or, at a higher dose, placental glucose transporter expression would be down-regulated.

In another study of ours, the glucocorticoid effect on the glucose transporters in the diabetic rat placenta was questioned. It was hypothesized that GCs regulate placental glucose transport in many cell types and tissues and depending on this hypothesis the relationship between glucose transport and the glucocorticoid metabolism in rat placental development of normal and diabetic pregnancy was investigated. The immunohistochemical results indicated that GR and GLUT1 are expressed ubiquitously in the trophoblast and endothelial cells of the labyrinthine zone. Amounts of GR and GLUT1 proteins increased towards the end of gestation both in the control and the diabetic placenta. However, at days 17 and 19 of gestation, only the placental GR protein was significantly increased in the streptozotocin-induced diabetic rats compared to control rats. It is mentioned in this study that there might be a relationship between GR and GLUT1 expressions at the cellular level. GLUT1 does not play a pivotal role in diabetic pregnancies. However, placental growth abnormalities during diabetic pregnancy may be related with the amount of GR [145].

It was previously reported by Hahn et al. for the first time, that both GLUT1 and GLUT3 transcripts and protein were significantly down-regulated in isolated human trophoblast cells and in rat placentas by GCs, suggesting regulation at the transcriptional level [7]. Hyperglycemia is one of the well known systemic effects following GC treatment. Thus, elevated glucose concentrations might have affected placental GLUT expression [146]. However, in the rat model, a single injection of TA resulted in only short term 
hyperglycemia, followed by hypoglycemia. This hypoglycemia may be the reason for the smaller fetuses and placentas as well as for the markedly reduced weight gain of TAtreated rats during gestational days 16 and 21.The human trophoblast cells were cultured under physiological glucose concentrations, yet their GLUTs were down-regulated similar to those in TA-treated rats. Collectively, the investigators concluded that the synthetic GC Triamcinolone is a potent regulator of human and rodent placental GLUT1 and GLUT3 expression. This effect is mediated by the GR. They speculate that GC-induced downregulation of the placental glucose transporter systems contributes to the retarded fetal and placental growth observed with GC treatment. This would represent a pathogenetic mechanism different from that leading to intrauterine growth retardation in the absence of GC treatment, in which trophoblast GLUT1 is not altered [134]. However, it is difficult to determine the cause and effect relationships, and the growth restriction could occur first, followed by an appropriate down-regulation of the transporters so as to match fetal size.

Consistent with this study, it was also reported that GLUT1 and GLUT3 mRNA levels were decreased in the dexamethasone treated group in the caruncles of the caw placenta [147]. In this study, plasma glucose concentrations of cows carrying a somatic cell clone fetus during late pregnancy and GLUT mRNA levels at parturition were examined. Parturition was induced by using dexamethasone and some other molecules. Cotyledon and caruncle tissues were removed just after parturition and were used for mRNA extraction. In the caruncules of the Dex induced parturition group GLUT1 and GLUT3 mRNA levels were decreased according to the Clone Pregnancy.

In another rat model, female pregnant rats were subjected to \% 50 food restrictions in order to investigate the effect of maternal nutrient on placental GLUTs. In this model fetuses were overexposured to glucocorticoids as maternal protein restriction induces it. At day 21 of pregnancy plasma corticosterone levels were increased. Correspondingly, placental GLUT3 protein was decreased, GLUT1 and GLUT4 protein levels were not affected by maternal feeding regimen and therefore enhanced corticosterone level [148].

Besides placenta, GCs affect glucose transport in a variety of peripheral tissues, such as skeletal muscle, adipocytes, and endothelial cells [149-160]. High affinity low capacity GRs have been identified in the placenta of various species, including man, rat, and mouse [17, 35, 161, 162]. This would have important clinical implications, because GC-induced downregulation of the placental glucose transport system(s) may contribute to the deleterious side-effects of GC treatment during pregnancy, such as the higher incidence of growthretarded fetuses [46, 163-165].

Corticosteroids have also been shown to have major effects on fetal glucose homeostasis resulting in long-term persistence of these changes after birth in sheep and rats [166-172]. Prenatal corticosteroid exposure of mice resulted in programming of the fetus such that the adult progeny exhibited glucose intolerance [170, 171]. In addition, repeated courses of maternal corticosteroid administration have been shown to alter fetal glucose homeostasis and hepatic enzyme activity in rats $[157,173]$. 

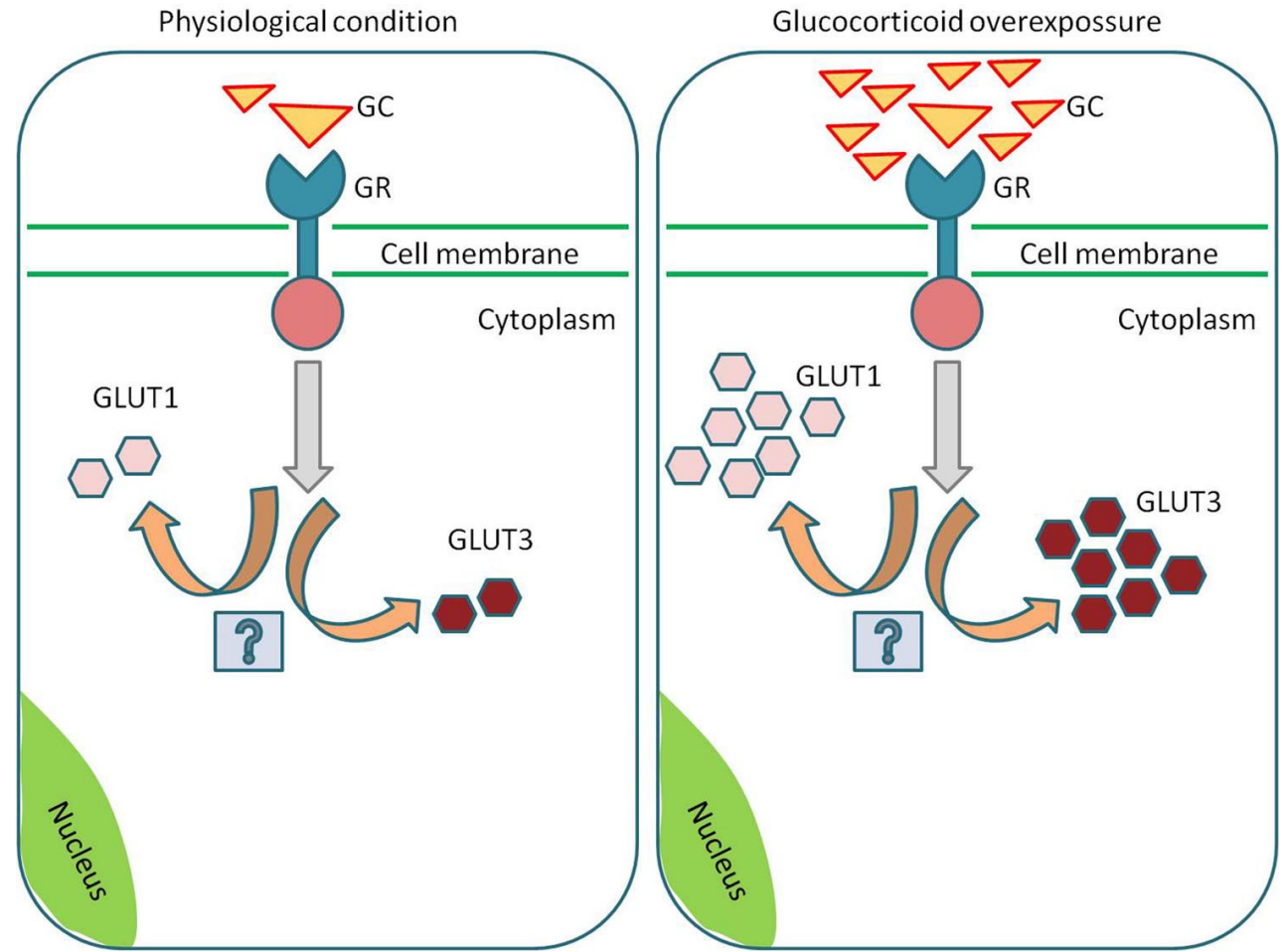

Figure 5. Effect of glucocorticoid overexposure on GLUT1 and GLUT3 expression in placental endothelial cells. GCs bind to GR and activate cellular signal transduction pathways. These molecular mechanisms remain to be unknown. As a result of GC overexposure GLUT1 and GLUT3 mRNA and proteins are increased in placental endothelial cells. Left panel refers possible physiological conditions and right panel refers effects of GC overexposure on GLUTs. (GC; Glucocorticoid, GR; Glucocorticoid Receptor, GLUT; Glucose Transporter)

In summary, the effects of glucocorticoids in placental glucose transport mechanisms in not fully understood. Further studies are needed to explain this issue.

\section{Conclusion}

Placental and fetal development is effected from glucocorticoids. Physiological glucocorticoid concentrations are necessary for healthy implantation, and pregnancy processes. On the other hand, glucocorticoid overexposure results with fetal and placental defects. Placentas of dexamethasone treated animals are smaller than healthy ones. In IUGR group placentas reduced placental proliferation and induced apoptosis seem to be a reason for decreased placental weigths. Dexamethasone caused a decrease in expression of genes involved in cell division such as cyclins A2, B1, D2, CDK 2, CDK 4 and M-phase protein kinase along with growth-promoting genes such as epidermal growth factor receptor. Moreover, in IUGR placentas cell cycle promoter proteins PCNA, Ki67 is decreased and cell 
cycle inhibitor proteins p27 and 57 are increased. Altered MAPK and Akt pathways are also unfavorably affected from glucocorticoid treatment. Decreased Akt and MAPK activations would result with reduced proliferation and/or induced apoptosis and reduced angiogenesis. GCs may affect placental angiogenesis by altering VEGF, VEGFR1 and VEGFR2 expression both at protein and gene levels with a direct effect on endothelial cells. Besides, without effecting endothelial cell viability and proliferation, GCs may affect endothelial cell migration and/or capacity of tube formation. The indirect effects of GCs seem to be via altering placental cytokine production processes which have negative effects on angiogenesis mechanisms. Another mechanism by which GCs may alter placental development is glucose transport mechanisms. It seems that GCs affect Glucose transporters via cell type dependent manner. In human endothelial cells GCs will up-regulate GLUT1 and GLUT3 expression but in trophoblast cells GCs adversely down regulates GLUT1 and GLUT3 expression in vitro.

In summary glucocorticoid overexposure may alter fetal development by altering, in part, placental development and function. It is clearly reviewed that placental development, proliferation, angiogenesis and glucose transport mechanisms are negatively affected from excess maternal glucocorticoid.

\section{Author details}

Emin Turkay Korgun*, Aslı Ozmen, Gozde Unek

Akdeniz University, Medical Faculty, Histology and Embryology Department, Antalya, Turkey

Inanc Mendilcioglu

Akdeniz University, Medical Faculty, Obstetrics and Gynecology Department, Antalya, Turkey

\section{References}

[1] Munck A, Naray-Fejes-Toth A (1994) Glucocorticoids and stress: permissive and suppressive actions. Ann N Y Acad Sci 746: 115-30; discussion 131-3.

[2] McEwen BS (2007) Physiology and neurobiology of stress and adaptation: central role of the brain. Physiol Rev 87: 873-904.

[3] Roberts D, Dalziel S (2006) Antenatal corticosteroids for accelerating fetal lung maturation for women at risk of preterm birth. Cochrane Database Syst Rev 3: CD004454.

[4] Kennedy TG (1983) Prostaglandin E2, adenosine 3':5'-cyclic monophosphate and changes in endometrial vascular permeability in rat uteri sensitized for the decidual cell reaction. Biol Reprod 29: 1069-76.

[5] Lopez Bernal A, Rivera J, Europe-Finner GN, Phaneuf S, Asboth G (1995) Parturition: activation of stimulatory pathways or loss of uterine quiescence? Adv Exp Med Biol 395: 435-51.

\footnotetext{
${ }^{*}$ Corresponding Author
} 
[6] Guller S, Markiewicz L, Wozniak R, Burnham JM, Wang EY, Kaplan P, Lockwood CJ (1994) Developmental regulation of glucocorticoid-mediated effects on extracellular matrix protein expression in the human placenta. Endocrinology 134: 2064-71.

[7] Hahn T, Barth S, Graf R, Engelmann M, Beslagic D, Reul JM, Holsboer F, Dohr G, Desoye G (1999) Placental glucose transporter expression is regulated by glucocorticoids. J Clin Endocrinol Metab 84: 1445-52.

[8] Librach CL, Feigenbaum SL, Bass KE, Cui TY, Verastas N, Sadovsky Y, Quigley JP, French DL, Fisher SJ (1994) Interleukin-1 beta regulates human cytotrophoblast metalloproteinase activity and invasion in vitro. J Biol Chem 269: 17125-31.

[9] Xu B, Makris A, Thornton C, Hennessy A (2005) Glucocorticoids inhibit placental cytokines from cultured normal and preeclamptic placental explants. Placenta 26: 65460.

[10] Ma Y, Kadner SS, Guller S (2004) Differential effects of lipopolysaccharide and thrombin on interleukin- 8 expression in syncytiotrophoblasts and endothelial cells: implications for fetal survival. Ann N Y Acad Sci 1034: 236-44.

[11] Rosen T, Krikun G, Ma Y, Wang EY, Lockwood CJ, Guller S (1998) Chronic antagonism of nuclear factor-kappaB activity in cytotrophoblasts by dexamethasone: a potential mechanism for antiinflammatory action of glucocorticoids in human placenta. J Clin Endocrinol Metab 83: 3647-52.

[12] Tchernitchin A, Rooryck J, Tchernitchin X, Vandenhende J, Galand P (1975) Effects of cortisol on uterine eosinophilia and other oestrogenic responses. Mol Cell Endocrinol 2: 331-7.

[13] Fowden AL, Li J, Forhead AJ (1998) Glucocorticoids and the preparation for life after birth: are there long-term consequences of the life insurance? Proc Nutr Soc 57: 113-22.

[14] (2011) ACOG Committee Opinion No. 475: Antenatal corticosteroid therapy for fetal maturation. Obstet Gynecol 117: 422-4.

[15] Benediktsson R, Lindsay RS, Noble J, Seckl JR, Edwards CR (1993) Glucocorticoid exposure in utero: new model for adult hypertension. Lancet 341: 339-41.

[16] Levitt NS, Lindsay RS, Holmes MC, Seckl JR (1996) Dexamethasone in the last week of pregnancy attenuates hippocampal glucocorticoid receptor gene expression and elevates blood pressure in the adult offspring in the rat. Neuroendocrinology 64: 412-8.

[17] Bloom SL, Sheffield JS, McIntire DD, Leveno KJ (2001) Antenatal dexamethasone and decreased birth weight. Obstet Gynecol 97: 485-90.

[18] Langdown ML, Sugden MC (2001) Enhanced placental GLUT1 and GLUT3 expression in dexamethasone-induced fetal growth retardation. Mol Cell Endocrinol 185: 109-17.

[19] Sugden MC, Langdown ML, Munns MJ, Holness MJ (2001) Maternal glucocorticoid treatment modulates placental leptin and leptin receptor expression and materno-fetal leptin physiology during late pregnancy, and elicits hypertension associated with hyperleptinaemia in the early-growth-retarded adult offspring. Eur J Endocrinol 145: 529-39.

[20] Barker DJ (1997) Fetal nutrition and cardiovascular disease in later life. Br Med Bull 53: 96-108. 
[21] Uno H, Eisele S, Sakai A, Shelton S, Baker E, DeJesus O, Holden J (1994) Neurotoxicity of glucocorticoids in the primate brain. Horm Behav 28: 336-48.

[22] Lesage J, Blondeau B, Grino M, Breant B, Dupouy JP (2001) Maternal undernutrition during late gestation induces fetal overexposure to glucocorticoids and intrauterine growth retardation, and disturbs the hypothalamo-pituitary adrenal axis in the newborn rat. Endocrinology 142: 1692-702.

[23] Bertram CE, Hanson MA (2002) Prenatal programming of postnatal endocrine responses by glucocorticoids. Reproduction 124: 459-67.

[24] de Vries A, Holmes MC, Heijnis A, Seier JV, Heerden J, Louw J, Wolfe-Coote S, Meaney MJ, Levitt NS, Seckl JR (2007) Prenatal dexamethasone exposure induces changes in nonhuman primate offspring cardiometabolic and hypothalamic-pituitary-adrenal axis function. J Clin Invest 117: 1058-67.

[25] Matthews SG (2000) Antenatal glucocorticoids and programming of the developing CNS. Pediatr Res 47: 291-300.

[26] Kranendonk G, Hopster H, Fillerup M, Ekkel ED, Mulder EJ, Taverne MA (2006) Cortisol administration to pregnant sows affects novelty-induced locomotion, aggressive behaviour, and blunts gender differences in their offspring. Horm Behav 49: 663-72.

[27] Funder JW (1997) Glucocorticoid and mineralocorticoid receptors: biology and clinical relevance. Annu Rev Med 48: 231-40.

[28] Li X, Wong J, Tsai SY, Tsai MJ, O'Malley BW (2003) Progesterone and glucocorticoid receptors recruit distinct coactivator complexes and promote distinct patterns of local chromatin modification. Mol Cell Biol 23: 3763-73.

[29] Wang Z, Frederick J, Garabedian MJ (2002) Deciphering the phosphorylation "code" of the glucocorticoid receptor in vivo. J Biol Chem 277: 26573-80.

[30] Yang Z, Guo C, Zhu P, Li W, Myatt L, Sun K (2007) Role of glucocorticoid receptor and CCAAT/enhancer-binding protein alpha in the feed-forward induction of 11betahydroxysteroid dehydrogenase type 1 expression by cortisol in human amnion fibroblasts. J Endocrinol 195: 241-53.

[31] Sun K, Myatt L (2003) Enhancement of glucocorticoid-induced 11beta-hydroxysteroid dehydrogenase type 1 expression by proinflammatory cytokines in cultured human amnion fibroblasts. Endocrinology 144: 5568-77.

[32] Sun M, Ramirez M, Challis JR, Gibb W (1996) Immunohistochemical localization of the glucocorticoid receptor in human fetal membranes and decidua at term and preterm delivery. J Endocrinol 149: 243-8.

[33] Chan CC, Lao TT, Ho PC, Sung EO, Cheung AN (2003) The effect of mifepristone on the expression of steroid hormone receptors in human decidua and placenta: a randomized placebo-controlled double-blind study. J Clin Endocrinol Metab 88: 5846-50.

[34] Chan J, Rabbitt EH, Innes BA, Bulmer JN, Stewart PM, Kilby MD, Hewison M (2007) Glucocorticoid-induced apoptosis in human decidua: a novel role for 11betahydroxysteroid dehydrogenase in late gestation. J Endocrinol 195: 7-15.

[35] Korgun ET, Dohr G, Desoye G, Demir R, Kayisli UA, Hahn T (2003) Expression of insulin, insulin-like growth factor I and glucocorticoid receptor in rat uterus and 
embryo during decidualization, implantation and organogenesis. Reproduction 125: 7584 .

[36] Monder C, Shackleton CH (1984) 11 beta-Hydroxysteroid dehydrogenase: fact or fancy? Steroids 44: 383-417.

[37] Seckl JR (1993) 11 beta-hydroxysteroid dehydrogenase isoforms and their implications for blood pressure regulation. Eur J Clin Invest 23: 589-601.

[38] Seckl JR, Walker BR (2001) Minireview: 11beta-hydroxysteroid dehydrogenase type 1- a tissue-specific amplifier of glucocorticoid action. Endocrinology 142: 1371-6.

[39] Alfaidy N, Li W, MacIntosh T, Yang K, Challis J (2003) Late gestation increase in 11betahydroxysteroid dehydrogenase 1 expression in human fetal membranes: a novel intrauterine source of cortisol. J Clin Endocrinol Metab 88: 5033-8.

[40] Hardy DB, Yang K (2002) The expression of 11 beta-hydroxysteroid dehydrogenase type 2 is induced during trophoblast differentiation: effects of hypoxia. J Clin Endocrinol Metab 87: 3696-701.

[41] Krozowski Z, MaGuire JA, Stein-Oakley AN, Dowling J, Smith RE, Andrews RK (1995) Immunohistochemical localization of the 11 beta-hydroxysteroid dehydrogenase type II enzyme in human kidney and placenta. J Clin Endocrinol Metab 80: 2203-9.

[42] Sun K, Yang K, Challis JR (1997) Differential expression of 11 beta-hydroxysteroid dehydrogenase types 1 and 2 in human placenta and fetal membranes. J Clin Endocrinol Metab 82: 300-5.

[43] Driver PM, Kilby MD, Bujalska I, Walker EA, Hewison M, Stewart PM (2001) Expression of 11 beta-hydroxysteroid dehydrogenase isozymes and corticosteroid hormone receptors in primary cultures of human trophoblast and placental bed biopsies. Mol Hum Reprod 7: 357-63.

[44] Alfaidy N, Gupta S, DeMarco C, Caniggia I, Challis JR (2002) Oxygen regulation of placental 11 beta-hydroxysteroid dehydrogenase 2: physiological and pathological implications. J Clin Endocrinol Metab 87: 4797-805.

[45] Holmes MC, Abrahamsen CT, French KL, Paterson JM, Mullins JJ, Seckl JR (2006) The mother or the fetus? 11beta-hydroxysteroid dehydrogenase type 2 null mice provide evidence for direct fetal programming of behavior by endogenous glucocorticoids. J Neurosci 26: 3840-4.

[46] Edwards CR, Benediktsson R, Lindsay RS, Seckl JR (1993) Dysfunction of placental glucocorticoid barrier: link between fetal environment and adult hypertension? Lancet 341: 355-7.

[47] Lindsay RS, Lindsay RM, Waddell BJ, Seckl JR (1996) Prenatal glucocorticoid exposure leads to offspring hyperglycaemia in the rat: studies with the 11 beta-hydroxysteroid dehydrogenase inhibitor carbenoxolone. Diabetologia 39: 1299-305.

[48] Langley-Evans SC (1997) Maternal carbenoxolone treatment lowers birthweight and induces hypertension in the offspring of rats fed a protein-replete diet. Clin Sci (Lond) 93: 423-9.

[49] Welberg LA, Seckl JR, Holmes MC (2000) Inhibition of 11beta-hydroxysteroid dehydrogenase, the foeto-placental barrier to maternal glucocorticoids, permanently 
programs amygdala GR mRNA expression and anxiety-like behaviour in the offspring. Eur J Neurosci 12: 1047-54.

[50] Wyrwoll CS, Seckl JR, Holmes MC (2009) Altered placental function of 11betahydroxysteroid dehydrogenase 2 knockout mice. Endocrinology 150: 1287-93.

[51] Stewart PM, Rogerson FM, Mason JI (1995) Type 211 beta-hydroxysteroid dehydrogenase messenger ribonucleic acid and activity in human placenta and fetal membranes: its relationship to birth weight and putative role in fetal adrenal steroidogenesis. J Clin Endocrinol Metab 80: 885-90.

[52] Kajantie E, Dunkel L, Turpeinen U, Stenman UH, Andersson S (2006) Placental 11betaHSD2 activity, early postnatal clinical course, and adrenal function in extremely low birth weight infants. Pediatr Res 59: 575-8.

[53] Dave-Sharma S, Wilson RC, Harbison MD, Newfield R, Azar MR, Krozowski ZS, Funder JW, Shackleton CH, Bradlow HL, Wei JQ, Hertecant J, Moran A, Neiberger RE, Balfe JW, Fattah A, Daneman D, Akkurt HI, De Santis C, New MI (1998) Examination of genotype and phenotype relationships in 14 patients with apparent mineralocorticoid excess. J Clin Endocrinol Metab 83: 2244-54.

[54] Newnham JP, Evans SF, Godfrey M, Huang W, Ikegami M, Jobe A (1999) Maternal, but not fetal, administration of corticosteroids restricts fetal growth. J Matern Fetal Med 8: 81-7.

[55] Malassine A, Cronier L (2002) Hormones and human trophoblast differentiation: a review. Endocrine 19: 3-11.

[56] Morrish DW, Dakour J, Li H (1998) Functional regulation of human trophoblast differentiation. J Reprod Immunol 39: 179-95.

[57] Audette MC, Greenwood SL, Sibley CP, Jones CJ, Challis JR, Matthews SG, Jones RL (2010) Dexamethasone stimulates placental system A transport and trophoblast differentiation in term villous explants. Placenta 31: 97-105.

[58] Baisden B, Sonne S, Joshi RM, Ganapathy V, Shekhawat PS (2007) Antenatal dexamethasone treatment leads to changes in gene expression in a murine late placenta. Placenta 28: 1082-90.

[59] Hewitt DP, Mark PJ, Waddell BJ (2006) Glucocorticoids prevent the normal increase in placental vascular endothelial growth factor expression and placental vascularity during late pregnancy in the rat. Endocrinology 147: 5568-74.

[60] Hewitt DP, Mark PJ, Waddell BJ (2006) Placental expression of peroxisome proliferatoractivated receptors in rat pregnancy and the effect of increased glucocorticoid exposure. Biol Reprod 74: 23-8.

[61] Timmerman M, Teng C, Wilkening RB, Fennessey P, Battaglia FC, Meschia G (2000) Effect of dexamethasone on fetal hepatic glutamine-glutamate exchange. Am J Physiol Endocrinol Metab 278: E839-45.

[62] Ward JW, Wooding FB, Fowden AL (2004) Ovine feto-placental metabolism. J Physiol 554: 529-41.

[63] Fowden AL, Forhead AJ (2009) Hormones as epigenetic signals in developmental programming. Exp Physiol 94: 607-25. 
[64] Fowden AL, Forhead AJ, Coan PM, Burton GJ (2008) The placenta and intrauterine programming. J Neuroendocrinol 20: 439-50.

[65] McDonald TJ, Franko KL, Brown JM, Jenkins SL, Nathanielsz PW, Nijland MJ (2003) Betamethasone in the last week of pregnancy causes fetal growth retardation but not adult hypertension in rats. J Soc Gynecol Investig 10: 469-73.

[66] Kaufmann P, Castelluci M (1997) Extravillous trophoblast in the human placenta: A review. Trophoblast Research 18: 21-65.

[67] Lodish H, Berk A, Kaiser A, Krieger M, Scott P, Bretscher A, Ploegh H, Matsudaira P, Molecular Cell Biology. 5th ed. 2002, New York: W H Freeman.

[68] Alberts B, Johnson A, Lewis J, Raff M, Roberts K, Walter P, Molecular Biology of the Cell. 4th ed. 2002, New York Garland Science.

[69] Sherr CJ, Roberts JM (1995) Inhibitors of mammalian G1 cyclin-dependent kinases. Genes Dev 9: 1149-63.

[70] Xiong Y (1996) Why are there so many CDK inhibitors? Biochim Biophys Acta 1288: 015.

[71] Lew DJ, Dulic V, Reed SI (1991) Isolation of three novel human cyclins by rescue of G1 cyclin (Cln) function in yeast. Cell 66: 1197-206.

[72] Bailly E, Pines J, Hunter T, Bornens M (1992) Cytoplasmic accumulation of cyclin B1 in human cells: association with a detergent-resistant compartment and with the centrosome. J Cell Sci 101 ( Pt 3): 529-45.

[73] Hunter T, Pines J (1994) Cyclins and cancer. II: Cyclin D and CDK inhibitors come of age. Cell 79: 573-82.

[74] Harper JW, Elledge SJ (1996) Cdk inhibitors in development and cancer. Curr Opin Genet Dev 6: 56-64.

[75] Dulic V, Stein GH, Far DF, Reed SI (1998) Nuclear accumulation of p21Cip1 at the onset of mitosis: a role at the G2/M-phase transition. Mol Cell Biol 18: 546-57.

[76] Ogryzko VV, Wong P, Howard BH (1997) WAF1 retards S-phase progression primarily by inhibition of cyclin-dependent kinases. Mol Cell Biol 17: 4877-82.

[77] Niculescu AB, 3rd, Chen X, Smeets M, Hengst L, Prives C, Reed SI (1998) Effects of p21(Cip1/Waf1) at both the G1/S and the G2/M cell cycle transitions: pRb is a critical determinant in blocking DNA replication and in preventing endoreduplication. Mol Cell Biol 18: 629-43.

[78] Parker SB, Eichele G, Zhang P, Rawls A, Sands AT, Bradley A, Olson EN, Harper JW, Elledge SJ (1995) p53-independent expression of p21Cip1 in muscle and other terminally differentiating cells. Science 267: 1024-7.

[79] Lee MH, Reynisdottir I, Massague J (1995) Cloning of p57KIP2, a cyclin-dependent kinase inhibitor with unique domain structure and tissue distribution. Genes Dev 9: 639-49.

[80] Yan Y, Frisen J, Lee MH, Massague J, Barbacid M (1997) Ablation of the CDK inhibitor p57Kip2 results in increased apoptosis and delayed differentiation during mouse development. Genes Dev 11: 973-83. 
[81] Genbacev O, McMaster MT, Fisher SJ (2000) A repertoire of cell cycle regulators whose expression is coordinated with human cytotrophoblast differentiation. Am J Pathol 157: 1337-51.

[82] DeLoia JA, Burlingame JM, Krasnow JS (1997) Differential expression of G1 cyclins during human placentogenesis. Placenta 18: 9-16.

[83] Ichikawa N, Zhai YL, Shiozawa T, Toki T, Noguchi H, Nikaido T, Fujii S (1998) Immunohistochemical analysis of cell cycle regulatory gene products in normal trophoblast and placental site trophoblastic tumor. Int J Gynecol Pathol 17: 235-40.

[84] Korgun ET, Celik-Ozenci C, Acar N, Cayli S, Desoye G, Demir R (2006) Location of cell cycle regulators cyclin B1, cyclin A, PCNA, Ki67 and cell cycle inhibitors p21, p27 and p57 in human first trimester placenta and deciduas. Histochem Cell Biol 125: 615-24.

[85] Rossant J, Cross JC (2001) Placental development: lessons from mouse mutants. Nat Rev Genet 2: 538-48.

[86] Georgiades P, Ferguson-Smith AC, Burton GJ (2002) Comparative developmental anatomy of the murine and human definitive placentae. Placenta 23: 3-19.

[87] Pijnenborg R, Robertson WB, Brosens I, Dixon G (1981) Review article: trophoblast invasion and the establishment of haemochorial placentation in man and laboratory animals. Placenta 2: 71-91.

[88] Korgun ET, Unek G, Herrera E, Jones CJ, Wadsack C, Kipmen-Korgun D, Desoye G (2011) Mapping of CIP/KIP inhibitors, G1 cyclins D1, D3, E and p53 proteins in the rat term placenta. Histochem Cell Biol 136: 267-78.

[89] Unek G, Ozmen A, Kipmen-Korgun D, Korgun ET (2012) Immunolocalization of PCNA, Ki67, p27 and p57 in normal and dexamethasone-induced intrauterine growth restriction placental development in rat. Acta Histochem 114: 31-40.

[90] Kim ST, Lee SK, Gye MC (2005) The expression of Cdk inhibitors p27kip1 and p57kip2 in mouse placenta and human choriocarcinoma JEG-3 cells. Placenta 26: 73-80.

[91] Ozmen A, Unek G, Kipmen-Korgun D, Korgun ET (2011) The expression of Akt and ERK1/2 proteins decreased in dexamethasone-induced intrauterine growth restricted rat placental development. J Mol Histol 42: 237-49.

[92] Ain R, Canham LN, Soares MJ (2005) Dexamethasone-induced intrauterine growth restriction impacts the placental prolactin family, insulin-like growth factor-II and the Akt signaling pathway. J Endocrinol 185: 253-63.

[93] Ghidini A, Pezzullo JC, Sylvestre G, Lembet A, Salafia CM (2001) Antenatal corticosteroids and placental histology in preterm birth. Placenta 22: 412-7.

[94] Gennari-Moser C, Khankin EV, Schuller S, Escher G, Frey BM, Portmann CB, Baumann MU, Lehmann AD, Surbek D, Karumanchi SA, Frey FJ, Mohaupt MG (2011) Regulation of placental growth by aldosterone and cortisol. Endocrinology 152: 263-71.

[95] Waddell BJ, Hisheh S, Dharmarajan AM, Burton PJ (2000) Apoptosis in rat placenta is zone-dependent and stimulated by glucocorticoids. Biol Reprod 63: 1913-7.

[96] Crocker IP, Barratt S, Kaur M, Baker PN (2001) The in-vitro characterization of induced apoptosis in placental cytotrophoblasts and syncytiotrophoblasts. Placenta 22: 822-30. 
[97] Mandl M, Ghaffari-Tabrizi N, Haas J, Nohammer G, Desoye G (2006) Differential glucocorticoid effects on proliferation and invasion of human trophoblast cell lines. Reproduction 132: 159-67.

[98] Clapp C, Thebault S, Jeziorski MC, Martinez De La Escalera G (2009) Peptide hormone regulation of angiogenesis. Physiol Rev 89: 1177-215.

[99] Lunghi L, Pavan B, Biondi C, Paolillo R, Valerio A, Vesce F, Patella A (2010) Use of glucocorticoids in pregnancy. Curr Pharm Des 16: 3616-37.

[100] Hadoke PW, Iqbal J, Walker BR (2009) Therapeutic manipulation of glucocorticoid metabolism in cardiovascular disease. Br J Pharmacol 156: 689-712.

[101] Oberleithner H, Schneider SW, Albermann L, Hillebrand U, Ludwig T, Riethmuller C, Shahin V, Schafer C, Schillers H (2003) Endothelial cell swelling by aldosterone. J Membr Biol 196: 163-72.

[102] Yang S, Zhang L (2004) Glucocorticoids and vascular reactivity. Curr Vasc Pharmacol 2: 1-12.

[103] Rae M, Mohamad A, Price D, Hadoke PW, Walker BR, Mason JI, Hillier SG, Critchley HO (2009) Cortisol inactivation by 11beta-hydroxysteroid dehydrogenase-2 may enhance endometrial angiogenesis via reduced thrombospondin-1 in heavy menstruation. J Clin Endocrinol Metab 94: 1443-50.

[104] Carmeliet P (2000) Mechanisms of angiogenesis and arteriogenesis. Nat Med 6: 389-95.

[105] Logie JJ, Ali S, Marshall KM, Heck MM, Walker BR, Hadoke PW (2010) Glucocorticoidmediated inhibition of angiogenic changes in human endothelial cells is not caused by reductions in cell proliferation or migration. PLoS One 5: e14476.

[106] Giroux S, Tremblay M, Bernard D, Cardin-Girard JF, Aubry S, Larouche L, Rousseau S, Huot J, Landry J, Jeannotte L, Charron J (1999) Embryonic death of Mek1-deficient mice reveals a role for this kinase in angiogenesis in the labyrinthine region of the placenta. Curr Biol 9: 369-72.

[107] Hatano N, Mori Y, Oh-hora M, Kosugi A, Fujikawa T, Nakai N, Niwa H, Miyazaki J, Hamaoka T, Ogata M (2003) Essential role for ERK2 mitogen-activated protein kinase in placental development. Genes Cells 8: 847-56.

[108] Mikula M, Schreiber M, Husak Z, Kucerova L, Ruth J, Wieser R, Zatloukal K, Beug H, Wagner EF, Baccarini M (2001) Embryonic lethality and fetal liver apoptosis in mice lacking the c-raf-1 gene. EMBO J 20: 1952-62.

[109] Qian X, Esteban L, Vass WC, Upadhyaya C, Papageorge AG, Yienger K, Ward JM, Lowy DR, Santos E (2000) The Sos1 and Sos2 Ras-specific exchange factors: differences in placental expression and signaling properties. EMBO J 19: 642-54.

[110] Karar J, Maity A (2011) PI3K/AKT/mTOR Pathway in Angiogenesis. Front Mol Neurosci 4: 51.

[111] Aida K, Wang XL, Wang J, Li C, McDonald TJ, Nathanielsz PW (2004) Effect of betamethasone administration to the pregnant baboon at 0.75 gestation on placental eNOS distribution and activity. Placenta 25: 780-7.

[112] Schwab M, Coksaygan T, Nathanielsz PW (2006) Betamethasone effects on ovine uterine and umbilical placental perfusion at the dose used to enhance fetal lung maturation. Am J Obstet Gynecol 194: 572-9. 
[113] Hunt JS, Chen HL, Miller L (1996) Tumor necrosis factors: pivotal components of pregnancy? Biol Reprod 54: 554-62.

[114] Moore KW, de Waal Malefyt R, Coffman RL, O'Garra A (2001) Interleukin-10 and the interleukin-10 receptor. Annu Rev Immunol 19: 683-765.

[115] Kahler C, Schleussner E, Moller A, Seewald HJ (2004) Doppler measurements in fetoplacental vessels after maternal betamethasone administration. Fetal Diagn Ther 19: 52-7.

[116] Oliver A, Ciulla TA (2006) Corticosteroids as antiangiogenic agents. Ophthalmol Clin North Am 19: 345-51, v.

[117] Challa JK, Gillies MC, Penfold PL, Gyory JF, Hunyor AB, Billson FA (1998) Exudative macular degeneration and intravitreal triamcinolone: 18 month follow up. Aust N Z J Ophthalmol 26: 277-81.

[118] Danis RP, Ciulla TA, Pratt LM, Anliker W (2000) Intravitreal triamcinolone acetonide in exudative age-related macular degeneration. Retina 20: 244-50.

[119] Martidis A, Miller DG, Ciulla TA, Danis RP, Moorthy RS (1999) Corticosteroids as an antiangiogenic agent for histoplasmosis-related subfoveal choroidal neovascularization.

J Ocul Pharmacol Ther 15: 425-8.

[120] Penfold PL, Gyory JF, Hunyor AB, Billson FA (1995) Exudative macular degeneration and intravitreal triamcinolone. A pilot study. Aust N Z J Ophthalmol 23: 293-8.

[121] Zein WM, Noureddin BN, Jurdi FA, Schakal A, Bashshur ZF (2006) Panretinal photocoagulation and intravitreal triamcinolone acetonide for the management of proliferative diabetic retinopathy with macular edema. Retina 26: 137-42.

[122] Ingber DE, Madri JA, Folkman J (1986) A possible mechanism for inhibition of angiogenesis by angiostatic steroids: induction of capillary basement membrane dissolution. Endocrinology 119: 1768-75.

[123] Stokes CL, Weisz PB, Williams SK, Lauffenburger DA (1990) Inhibition of microvascular endothelial cell migration by beta-cyclodextrin tetradecasulfate and hydrocortisone. Microvasc Res 40: 279-84.

[124] Tokida Y, Aratani Y, Morita A, Kitagawa Y (1990) Production of two variant laminin forms by endothelial cells and shift of their relative levels by angiostatic steroids. J Biol Chem 265: 18123-9.

[125] Greenberger S, Boscolo E, Adini I, Mulliken JB, Bischoff J (2010) Corticosteroid suppression of VEGF-A in infantile hemangioma-derived stem cells. N Engl J Med 362: 1005-13.

[126] Kluetz PG, Figg WD, Dahut WL (2010) Angiogenesis inhibitors in the treatment of prostate cancer. Expert Opin Pharmacother 11: 233-47.

[127] Weinstein RS, Wan C, Liu Q, Wang Y, Almeida M, O'Brien CA, Thostenson J, Roberson PK, Boskey AL, Clemens TL, Manolagas SC (2010) Endogenous glucocorticoids decrease skeletal angiogenesis, vascularity, hydration, and strength in aged mice. Aging Cell 9: 147-61.

[128] Yano A, Fujii Y, Iwai A, Kageyama Y, Kihara K (2006) Glucocorticoids suppress tumor angiogenesis and in vivo growth of prostate cancer cells. Clin Cancer Res 12: 3003-9. 
[129] Pao SS, Paulsen IT, Saier MH, Jr. (1998) Major facilitator superfamily. Microbiol Mol Biol Rev 62: 1-34.

[130] Thorens B, Mueckler M (2010) Glucose transporters in the 21st Century. Am J Physiol Endocrinol Metab 298: E141-5.

[131] Joost HG, Bell GI, Best JD, Birnbaum MJ, Charron MJ, Chen YT, Doege H, James DE, Lodish HF, Moley KH, Moley JF, Mueckler M, Rogers S, Schurmann A, Seino S, Thorens B (2002) Nomenclature of the GLUT/SLC2A family of sugar/polyol transport facilitators. Am J Physiol Endocrinol Metab 282: E974-6.

[132] Farrell CL, Yang J, Pardridge WM (1992) GLUT-1 glucose transporter is present within apical and basolateral membranes of brain epithelial interfaces and in microvascular endothelia with and without tight junctions. J Histochem Cytochem 40: 193-9.

[133] Takata K, Kasahara T, Kasahara M, Ezaki O, Hirano H (1992) Localization of erythrocyte/HepG2-type glucose transporter (GLUT1) in human placental villi. Cell Tissue Res 267: 407-12.

[134] Jansson T, Wennergren M, Illsley NP (1993) Glucose transporter protein expression in human placenta throughout gestation and in intrauterine growth retardation. J Clin Endocrinol Metab 77: 1554-62.

[135] Illsley NP (2000) Glucose transporters in the human placenta. Placenta 21: 14-22.

[136] Xing AY, Challier JC, Lepercq J, Cauzac M, Charron MJ, Girard J, Hauguel-de Mouzon $S$ (1998) Unexpected expression of glucose transporter 4 in villous stromal cells of human placenta. J Clin Endocrinol Metab 83: 4097-101.

[137] Wolf HJ, Desoye G (1993) Immunohistochemical localization of glucose transporters and insulin receptors in human fetal membranes at term. Histochemistry 100: 379-85.

[138] Hahn D, Blaschitz A, Korgun ET, Lang I, Desoye G, Skofitsch G, Dohr G (2001) From maternal glucose to fetal glycogen: expression of key regulators in the human placenta. Mol Hum Reprod 7: 1173-8.

[139] Hauguel-de Mouzon S, Challier JC, Kacemi A, Cauzac M, Malek A, Girard J (1997) The GLUT3 glucose transporter isoform is differentially expressed within human placental cell types. J Clin Endocrinol Metab 82: 2689-94.

[140] Korgun ET, Celik-Ozenci C, Seval Y, Desoye G, Demir R (2005) Do glucose transporters have other roles in addition to placental glucose transport during early pregnancy? Histochem Cell Biol 123: 621-9.

[141] Hauguel-de Mouzon S, Shafrir E (2001) Carbohydrate and fat metabolism and related hormonal regulation in normal and diabetic placenta. Placenta 22: 619-27.

[142] Kalhan SC, D'Angelo LJ, Savin SM, Adam PA (1979) Glucose production in pregnant women at term gestation. Sources of glucose for human fetus. J Clin Invest 63: 388-94.

[143] Kipmen-Korgun D, Ozmen A, Unek G, Simsek M, Demir R, Korgun ET (2011) Triamcinolone up-regulates GLUT 1 and GLUT 3 expression in cultured human placental endothelial cells. Cell Biochem Funct.

[144] Anderson GG, Lamden MP, Cidlowski JA, Ashikaga T (1981) Comparative pulmonary surfactant-inducing effect of three corticosteroids in the near-term rat. Am J Obstet Gynecol 139: 562-4. 
[145] Korgun ET, Acar N, Sati L, Kipmen-Korgun D, Ozen A, Unek G, Ustunel I, Demir R (2011) Expression of glucocorticoid receptor and glucose transporter-1 during placental development in the diabetic rat. Folia Histochem Cytobiol 49: 325-34.

[146] Hahn T, Barth S, Weiss U, Mosgoeller W, Desoye G (1998) Sustained hyperglycemia in vitro down-regulates the GLUT1 glucose transport system of cultured human term placental trophoblast: a mechanism to protect fetal development? FASEB J 12: 1221-31.

[147] Hirayama H, Sawai K, Hirayama M, Hirai T, Kageyama S, Onoe S, Minamihashi A, Moriyasu S (2011) Prepartum maternal plasma glucose concentrations and placental glucose transporter mRNA expression in cows carrying somatic cell clone fetuses. J Reprod Dev 57: 57-61.

[148] Lesage J, Hahn D, Leonhardt M, Blondeau B, Breant B, Dupouy JP (2002) Maternal undernutrition during late gestation-induced intrauterine growth restriction in the rat is associated with impaired placental GLUT3 expression, but does not correlate with endogenous corticosterone levels. J Endocrinol 174: 37-43.

[149] Boyett JD, Hofert JF (1972) Studies concerning the inhibition of glucose metabolism in thymus lymphocytes by cortisol and epinephrine. Endocrinology 91: 233-9.

[150] Garvey WT, Huecksteadt TP, Monzon R, Marshall S (1989) Dexamethasone regulates the glucose transport system in primary cultured adipocytes: different mechanisms of insulin resistance after acute and chronic exposure. Endocrinology 124: 2063-73.

[151] Haber RS, Weinstein SP (1992) Role of glucose transporters in glucocorticoid-induced insulin resistance. GLUT4 isoform in rat skeletal muscle is not decreased by dexamethasone. Diabetes 41: 728-35.

[152] Hajduch E, Hainault I, Meunier C, Jardel C, Hainque B, Guerre-Millo M, Lavau M (1995) Regulation of glucose transporters in cultured rat adipocytes: synergistic effect of insulin and dexamethasone on GLUT4 gene expression through promoter activation. Endocrinology 136: 4782-9.

[153] Langdown ML, Holness MJ, Sugden MC (2001) Early growth retardation induced by excessive exposure to glucocorticoids in utero selectively increases cardiac GLUT1 protein expression and Akt/protein kinase B activity in adulthood. J Endocrinol 169: 1122.

[154] Olgemoller B, Schon J, Wieland OH (1985) Endothelial plasma membrane is a glucocorticoid-regulated barrier for the uptake of glucose into the cell. Mol Cell Endocrinol 43: 165-71.

[155] Weinstein SP, Wilson CM, Pritsker A, Cushman SW (1998) Dexamethasone inhibits insulin-stimulated recruitment of GLUT4 to the cell surface in rat skeletal muscle. Metabolism 47: 3-6.

[156] Ewart HS, Somwar R, Klip A (1998) Dexamethasone stimulates the expression of GLUT1 and GLUT4 proteins via different signalling pathways in L6 skeletal muscle cells. FEBS Lett 421: 120-4.

[157] Gray S, Stonestreet BS, Thamotharan S, Sadowska GB, Daood M, Watchko J, Devaskar SU (2006) Skeletal muscle glucose transporter protein responses to antenatal glucocorticoids in the ovine fetus. J Endocrinol 189: 219-29. 
[158] Hernandez R, Teruel T, Lorenzo M (2003) Insulin and dexamethasone induce GLUT4 gene expression in foetal brown adipocytes: synergistic effect through CCAAT/enhancer-binding protein alpha. Biochem J 372: 617-24.

[159] Lundgren M, Buren J, Ruge T, Myrnas T, Eriksson JW (2004) Glucocorticoids downregulate glucose uptake capacity and insulin-signaling proteins in omental but not subcutaneous human adipocytes. J Clin Endocrinol Metab 89: 2989-97.

[160] Tortorella LL, Pilch PF (2002) C2C12 myocytes lack an insulin-responsive vesicular compartment despite dexamethasone-induced GLUT4 expression. Am J Physiol Endocrinol Metab 283: E514-24.

[161] Costedoat-Chalumeau N, Amoura Z, Le Thi Hong D, Wechsler B, Vauthier D, Ghillani P, Papo T, Fain O, Musset L, Piette JC (2003) Questions about dexamethasone use for the prevention of anti-SSA related congenital heart block. Ann Rheum Dis 62: 1010-2.

[162] Matthews SG, Owen D, Kalabis G, Banjanin S, Setiawan EB, Dunn EA, Andrews MH (2004) Fetal glucocorticoid exposure and hypothalamo-pituitary-adrenal (HPA) function after birth. Endocr Res 30: 827-36.

[163] Garvey D, Scott J (1981) Placental and fetal contraindications of dexamethasone administration to pregnant rats. Experientia 37: 757-9.

[164] Katz VL, Thorp JM, Jr., Bowes WA, Jr. (1990) Severe symmetric intrauterine growth retardation associated with the topical use of triamcinolone. Am J Obstet Gynecol 162: 396-7.

[165] Reinisch JM, Simon NG, Karow WG, Gandelman R (1978) Prenatal exposure to prednisone in humans and animals retards intrauterine growth. Science 202: 436-8.

[166] Gatford KL, Wintour EM, De Blasio MJ, Owens JA, Dodic M (2000) Differential timing for programming of glucose homoeostasis, sensitivity to insulin and blood pressure by in utero exposure to dexamethasone in sheep. Clin Sci (Lond) 98: 553-60.

[167] Gurrin LC, Moss TJ, Sloboda DM, Hazelton ML, Challis JR, Newnham JP (2003) Uising WinBUGS to fit nonlinear mixed models with an application to pharmacokinetic modelling of insulin response to glucose challenge in sheep exposed antenatally to glucocorticoids. J Biopharm Stat 13: 117-39.

[168] Kutzler MA, Molnar J, Schlafer DH, Kuc RE, Davenport AP, Nathanielsz PW (2003) Maternal dexamethasone increases endothelin-1 sensitivity and endothelin a receptor expression in ovine foetal placental arteries. Placenta 24: 392-402.

[169] Moss TJ, Sloboda DM, Gurrin LC, Harding R, Challis JR, Newnham JP (2001) Programming effects in sheep of prenatal growth restriction and glucocorticoid exposure. Am J Physiol Regul Integr Comp Physiol 281: R960-70.

[170] Nyirenda MJ, Lindsay RS, Kenyon CJ, Burchell A, Seckl JR (1998) Glucocorticoid exposure in late gestation permanently programs rat hepatic phosphoenolpyruvate carboxykinase and glucocorticoid receptor expression and causes glucose intolerance in adult offspring. J Clin Invest 101: 2174-81.

[171] Nyirenda MJ, Welberg LA, Seckl JR (2001) Programming hyperglycaemia in the rat through prenatal exposure to glucocorticoids-fetal effect or maternal influence? J Endocrinol 170: 653-60. 
[172] Sloboda DM, Newnham JP, Challis JR (2000) Effects of repeated maternal betamethasone administration on growth and hypothalamic-pituitary-adrenal function of the ovine fetus at term. J Endocrinol 165: 79-91.

[173] Drake AJ, Walker BR, Seckl JR (2005) Intergenerational consequences of fetal programming by in utero exposure to glucocorticoids in rats. Am J Physiol Regul Integr Comp Physiol 288: R34-8. 